\title{
TERÜLETI EGYENLÓTLENSÉGEK AZ EURÓPAI UNIÓ, ILLETVE ROMÁNIA RÉGIÓIBAN
}

\section{TERRITORIAL INEQUALITIES IN EUROPEAN UNION AND IN ROMANIAN REGIONS}

\author{
Nagy Szeréna ${ }^{1}$ \\ 1Debreceni Egyetem, Vidékfejlesztés, Regionális Gazdaságtan és Turizmusmenedzsment Intézet, \\ Ihrig Károly Gazdálkodás- és Szervezéstudományok Doktori Iskola
}

\author{
Kulcsszavak: \\ Egyenlőtlenségek \\ Területi különbségek \\ Regionális fejlődés \\ Románia régiói

\section{Keywords: \\ Inequalities \\ Territorial disparities \\ Regional development \\ Romanian regions}

\begin{abstract}
Összefoglalás
A gazdasági és társadalmi egyenlötlenségek gyors növekedése az egyik legmeghatározóbb térbeli folyamatnak nevezhető. Az Európai Unió régiói közötti gazdasági különbségek mind politikai, mind gazdasági kutatások szempontjából állandó vizsgálatra adnak okot. Románia egyike azon európai uniós országoknak, amely esetében erőteljes a regionális egyenlötlenségi szint. A tanulmány célja, hogy röviden bemutassa Románia régióinak gazdasági, jövedelmi egyenlötlenségeit a 2014-2018-as időintervallumot vizsgálva.

\section{Abstract}

The quickly increasing of economic and social inequalities are the most prominent territorial process. Economic disparities between the regions of the European Union are of constant concern both for policy and economic research. Romania is one of the European Union countries within regional inequality is high. The purpose of the study is to present the evolution of the economic and income disparities in the romanian regions by examining the period of 2014-2018.
\end{abstract}

\section{Bevezetés}

Az egyenlőtlenség egy olyan fontos és aktuális téma, amelyet a történelem folyamán már számtalan perspektívából vizsgáltak. Jane Austen és Honoré de Balzac regényei például hiteles képet festenek a vagyon eloszlásáról Nagy-Britanniában és Franciaországban az 1790 és 1830 közötti időszakban. Számos közgazdász is vizsgálta a témakört, közülük okvetlen ki kell emelni Joseph Stiglitz (2012), Angus Deaton (2015) vagy Thomas Piketty (2015) munkáját. Az előbb említett múvek szerzői különböző elméleteket, megoldási alternatívákat közöltek, de egységesen elfogadott, minden ország számára megfelelő megoldás még nem született. Napjainkban egyre inkább megfigyelhető a növekvő társadalmi, gazdasági egyenlőtlenség. A gazdaság és a társadalom egy térben helyezkedik el, ami viszont lényeges, hogy a gazdasági egységek koncentrálódása térben ott a legintenzívebb, ahol a legbiztonságosabbak, legkedvezőbbek a feltételek a termeléshez [1]. Ilyen tekintetben tehát a termelési tényezők, mint a munka, a tőke, a természeti erőforrások és a technológiai ismeretek egyenlőtlenül oszlanak meg a térben, illetve egyenlőtlen a kereslet is irántuk. Az is tény, hogy az 
Európai Unió területén belül is óriásiak a területi különbségek, például a London és Észak-nyugat Románia régiók GDP-je közötti különbséget vizsgálva megállapítható, hogy 2011-ben Inner London régió egy főre jutó GDP-je több mint tizenegyszerese volt a romániai Észak Nyugat (Nord-Est) régióénak [2], illetve 2008-ban Luxemburg hétszer „gazdagabb” volt Romániánál [3]. Közép-KeletEurópa egyik legjelentősebb térbeli folyamata a gazdasági és társadalmi egyenlótlenségek gyors növekedése, illetve a fejlődés erős koncentrációja a fővárosi térségekben. Románia esetében is kijelenthető, hogy a regionális egyenlőtlenségi szint az EU viszonylatában az egyik legjelentősebb, illetve a jövedelmi egyenlőtlenségek tekintetében a román állampolgárok „felsőosztályának ${ }^{1}$ ” 20\%-a körülbelül nyolcszor magasabb jövedelemmel rendelkezik, mint az “alsóosztály” 20\%-a [4].

A területi egyenlőtlenségen az Európai Unióban olyan jelenségeket értenek, amelyek a társadalom, a gazdaság, a kultúra, valamint a demográfia dimenzióit érintve és abból építkezve alakulnak ki, emellett területi aspektussal is rendelkeznek. Ezen jelenségek igen fontos szereplői a nemzeti kormányok, illetve szervezetek, a helyi önkormányzatok, intézmények, vállalatok, illetve az egyének [1] [5]. Nyilvánvaló, hogy a területi egyenlőtlenségek kialakulásának egyik oka, hogy folyamatosan bekövetkeznek bizonyos területi és gazdasági változások. Másfelől amennyiben egyegy területen kedvezőtlen gazdasági körülmények alakulnak ki, azokra különböző társadalmi válaszok születtek, mint például az elvándorlás. Az egyes régiók, kistérségek társadalmi, gazdasági helyzetét az alapvető kelet-nyugat, centrum-periféria, főváros-vidék viszonylatokon túl a régiók gazdasági ereje, a munkahelyek száma, és a közszolgáltatásokkal, infrastruktúrával való ellátottsága befolyásolja számottevően [5] [6].

\section{Románia Régióinak általános bemutatása}

Románia egy kelet-közép-európai állam, amelynek területe $238391 \mathrm{~km}^{2}$, ezáltal a 11. helyen szerepel a területi nagysági sorrendben európai viszonylatban. Románia lakossága 19,53 millió volt 2018-ban, ebből 51,1\% nő, illetve 48,9\% férfi [7]. Az 1987-es Római Európai Egységokmányban megfogalmazott regionális célok szükségessé tették az egységes területi statisztikai osztályozási rendszer kialakítását. Ennek tekintetében Romániában a Nuts 1-es szint négy nagyrégiót foglal magában, a Nuts 2-es szint nyolc fejlsztési régiót, a Nuts 3-as szint 42 megyét. A lokális Nuts 4-et nem alakították ki Romániában és a NUTS 5 pedig 3174 települési - község, város, municípium, azaz megyei jogú város - önkormányzatot foglal magába [8]. Az 1-es ábra tartalmazza Románia nyolc fejlesztési régióját.

\footnotetext{
${ }^{1}$ A "felsőosztály" a társadalom azon 10\%-a, amelyet decilisnek nevezünk, illetve ezen $10 \%$ felső $1 \%$-át centilisnek nevezzük. A "középosztályhoz" a társadalom 40\%-a tartozik és az "alsóosztály" alkotja a fennmaradó 50\%-ot [24]
} 


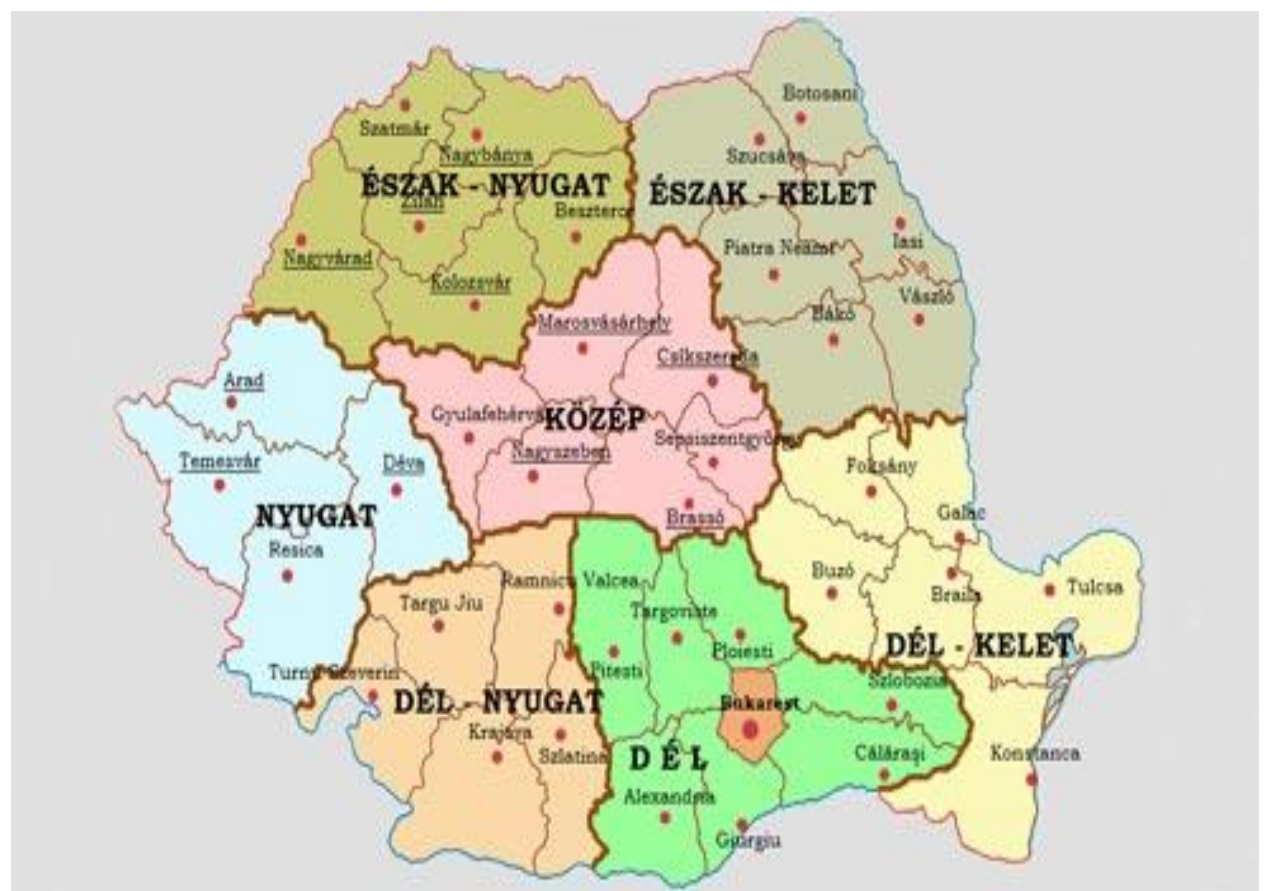

1. ábra Romániai régiói [8]

A fejlesztési régiókat 1998-ban a 151-es számú Törvényrendelet alapján hozták létre Romániában, amelynek célja, hogy Románia regionális felosztása az Európai Uniós szabályok szerint legyen kategorizálva, illetve a jelenlegi romániai megyék az 1968-as „megyésítés” eredményeképpen jöttek létre. Románia jelenleg 41 megyére és Bukarest municípiumra tagolódik [9] [8]. Az 1-es táblázat tartalmazza Románia fejlesztési régióit és megyéit.

1. táblázat Romániai régió és megyéi [8]

\begin{tabular}{|c|c|}
\hline $\begin{array}{c}\text { Gazdasági fejlesztési } \\
\text { régió }\end{array}$ & Megye \\
\hline $\begin{array}{c}\text { ÉSZAK - NYUGAT } \\
\text { RÉGIÓ }\end{array}$ & $\begin{array}{c}\text { Bihar, Beszterce-Naszód, Kolozs, Máramaros, Szatmár, } \\
\text { Szilágy }\end{array}$ \\
\hline ÉSZAK - KELET RÉGIÓ & Bákó, Botosani, Iasi, Neamt, Suceava, Vaslui \\
\hline NYUGAT RÉGIÓ & Arad, Krassó-Szörény, Hunyad, Temes \\
\hline KÖZÉP RÉGIÓ & Fehér, Brassó, Kovászna, Hargita, Maros, Szeben \\
\hline DÉL - NYUGAT RÉGIÓ & Dolj, Gorj, Mehedinti, Olt, Valcea \\
\hline $\begin{array}{c}\text { DÉLI -RÉGIÓ } \\
\text { DÉL - KELET RÉGIÓ }\end{array}$ & $\begin{array}{c}\text { Arges, Calaras, Dambovita, Giurgiu, Ialomita, Prahova, } \\
\text { Teleorman }\end{array}$ \\
\hline $\begin{array}{c}\text { BUKAREST-ILFOV } \\
\text { RÉGIÓ }\end{array}$ & \\
\end{tabular}

Az Észak-keleti régiónak a legnagyobb a területe és a legnépesebb is Románia régiói közül, fejlettsége ugyanakkor elmarad az ország más részeivel összevetve. Az előbb említett régió fontos szerepet tulajdonít a napenergia termelésnek, a szélenergia, illetve biomassza termelésnek. A Dél-keleti régió 
kulturális szempontból a legszínesebb, ugyanis magába foglal két megyét Moldovából, kettőt Munténiából és kettőt Dobrudzsából. Gazdasági fejlettség szempontjából a Dél-keleti régió közelít az országos átlaghoz. A Déli-régió, amely annak ellenére sem számít igazán fejlettnek gazdasági szempontból, hogy magába foglal három gazdaságilag fejlett és jól teljesítő megyét is (Prahova, Dâmboviță, Argeș), de ezek pozitív hatását ellensúlyozza a többi megye. A Dél-nyugati régió gazdasági teljesítmény, illetve fejlettség szempontjából hasonló a Dél-keleti régióhoz [9]. A Nyugatirégió a második legfejlettebb régió Bukarest-Ilfov régió után, illetve ezt követi az Észak-nyugati régió, amely fejlettebbnek tekinthető, gazdasági mutatók szempontjából közelít az országos átlaghoz. A Közép-régió a fejlettségi rangsorban a harmadik helyen található, illetve gazdaságilag kiegyensúlyozott a struktúrája, amely esetében az ipar továbbra is jelentős szereppel rendelkezik és gyorsan növekvő tercier szektorral bír. Nyilvánvaló, hogy gazdaságilag a legfejlettebb és a legerősebb régió nem más, mint Bukaest-Ilfov régió, amely tartalmazza a fővárost is [9] [10] [11] [12].

\section{A romániai, illetve az EU régiói közötti egyenlőtlenségek bemutatása}

Az Európai Parlament által kiadott 2019-es regionális egyenlőtlenségek elemzése szerint a NUTS2es régiókból 101 esetében a GDP az európai uniós átlag alatt van. A nyugati régiók esetében a GDP aránya hatszor nagyobb, mint az európai uniós átlag [12].

Az Európai Bizottság minden évben elkészít egy regionális versenyképességi listát. Ennek alapja a versenyképesség fogalma, amely jelen esetben magába foglalja egy adott ország, avagy régió azon képességét, hogy vonzó, fenntartható környezetet tudjon biztosítani a lakosságnak, illetve a befektetői, vállalkozói szférának is. Az Európai Bizottság értelmezésében a versenyképességi index olyan mutatók összességét tartalmazza, amelyek alapján megállapítható, hogy az adott régióban mennyire jó élni, dolgozni és vállalkozni. Tehát mit is foglal magába ez a komplex versenyképességi mutató igazából? Az ország gazdasági stabilitását, az infrastruktúra fejlettségi szintjét, az egészségügyi rendszert, az alapfokú (kötelező) oktatást, illetve a felsőoktatást, valamint munkaerőpiaci mutatókat, az üzleti szféra aktivitását, az állami intézményrendszerek hatékonyságát [14]. A 2019-ben elkészített Európai Uniós regionális versenyképességi lista alapján első helyen van Stockholm 100 pontszámmal, majd ezt követi London és környező zónája 99,1 pontszámmal és Utrecht 99,o pontszámmal. A 268-as lista legutolsó helyét foglalja el a görögországi Voreio Aigaio régió o,oo pontszámmal, illetve a 267-ik helyen szerepel a romániai Dél-nyugati régiói 5,3-as pontszámmal. A romániai régiók esetében Bukarest-Ilfov régió érte el a legnagyobb ponszámot (55,92 pontszám), ennek eredményeként a 268-as versenyképességi listán a 151-ik helyet foglalja el. Sajnos a romániai régiók közül csak a Nyugat régió ért el 20,9-es pontszámot, illetve hat romániai régió esetében a pontszámok nem érték el a 20-as értéket sem. Az EU tíz legversenyképesebb régiójából három Nagy-Britanniában található, illetve a rangsor alsó tízes listájában öt görög és egy román régió szerepel. Az utóbbi esetében egyetlen régió sem érte el a 10-es pontszámot. Másfelól minden Európai Uniós országban, beleértve Romániát is, a centrum-periféria különbség szembeötlő, vagyis a főváros és környéke versenyképességi előnyben van az adott ország többi régióihoz képest [13][15] [14]. Abban az esetben, ha az EU-s átlaghoz viszonyítjuk Románia helyzetét, a 2. ábra alapján látható, hogy sajnos egyetlen mutató esetében sem érte el Románia az európai uniós átlagot. 


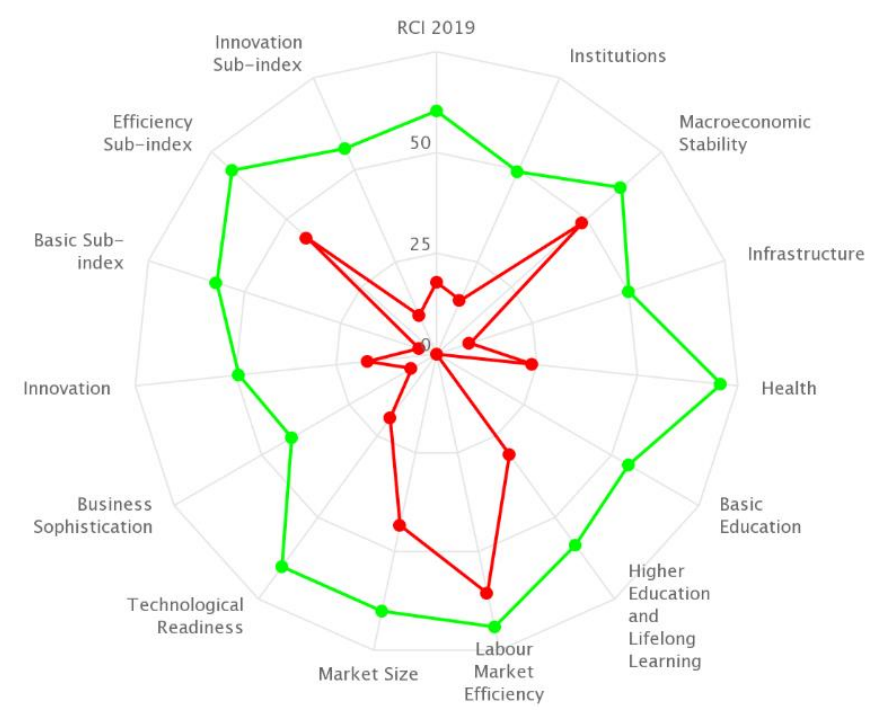

2. ábra Versenyképességi mutató [15]

Látható, hogy igen rossz a helyzet az oktatás és az infrastruktúra komponens esetében is, ugyanis például az infrastruktúra esetében az 50 pontos átlaghoz viszonyítva Románia mindössze 9 pontot kapott. De jelentős lemaradásban van Románia az innovációs képességet és az üzleti kifinomultságot tekintve is. Azokban a régiókban, ahol a versenyképességi mutató alacsony, jellemzően a regionális egyenlőtlenség is nagyobb. Románia, Bulgária, illetve Olaszország néhány régiójának esetében ez be is igazolódott. Abban az esetben, ha az EU-s átlaghoz viszonyítjuk Románia helyzetét, a fenti ábra alapján látható, hogy sajnos egyetlen mutató esetében sem érte el Románia az európai uniós átlagot [13] [14] [15].

A kormány már az 1990-es években diagnosztizálta az egyenlőtlenségek problémáját a régiók tekintetében, de a mai napig nem született előrelépés a megoldás irányába. Fontos lenne a befektetések ösztönzése és annak megfelelő elosztása az ország egyes régiói között, illetve az infrastruktúra fejlesztése [10]. Ugyanakkor egyes régiók sokkal nagyobb haszonélvezői lehetnek a befektetéseknek és az infrastrukturális fejlesztésnek, ennek eredményeként pedig az egyenlőtlenség mértéke nőni fog. Másfelől az egyenlőtlenségek kialakulásához Románia régióiban nagy mértékben hozzájárul a vidék és a város, vagyis a centrum, illetve periféria által okozott gazdasági és társadalmi egyenlőtlenség. Nyilvánvaló, hogy a városok, vagyis a centrumok sokkal fejlettebbek, illetve fontos tényező az is, hogy a lakosság nagyobb része városokban él (Románia lakosságának 53,6 \%-a városban él és csak 46,4\%-a vidéken a 2017-es adatok alapján [16]). Regionális szinten, a gazdasági növekedésben meghatározó szerepük van a városoknak, másfelől pedig a vidék elmaradottságát az is befolyásolja, hogy a centrum és periféria közötti gazdasági kapcsolat olykor nagyon gyenge. Nagyon sok esetben a perifériáról, vidékről járnak be dolgozni a centrumba.

\section{A régiók közötti gazdasági különbségek}

Történelmi áttekintésben Romániában az 1990-es években a rendszerváltás visszaesését követően stabilizálódtak a makrogazdasági folyamatok. 1999-ben az egy főre jutó GDP növekedésnek indult, 2001-ben elérte 5,7\%-os növekedést, amely részben a külföldi beruházásoknak köszönhető [10] [11]. Ezen pozitív változások ellenére is Románia régióinak egy főre jutó GDP-je jóval az EU átlag alatt maradt, kivételt képez a Bukarest-Ilfov Régió, amely eléri az EU-s átlagot [17]. Románia egyike azon országoknak, ahol a legnagyobb a régiók közötti egyenlőtlenség. Azokban az országokban, ahol az egy főre eső GDP alacsony, jellemzően erőteljesebben mutatkozik a szegényebb és a gazdagabb rétegek közötti jövedelmi egyenlőtlenség. Tehát Romániában erőteljes belső diszparitások alakultak ki, illetve a területi kohézió csökkent. Kettős folyamat ment végbe ugyanis, amely során a külső konvergenciát belső területi polarizáció kísérte [10] [18]. A 3. ábra alapján látható, hogy Bukarestet is magába foglaló Ilfov megye vette ki a részét a legnagyobb arányban az ország gazdasági 
teljesítményéből ugyanis 2017-ben a bruttó hazai össztermék 28,03\%-át (22000 Euró/fó), illetve 2018-ban 27,39\%-át (23349 Euró/fő) a főváros és környéke állította elő.

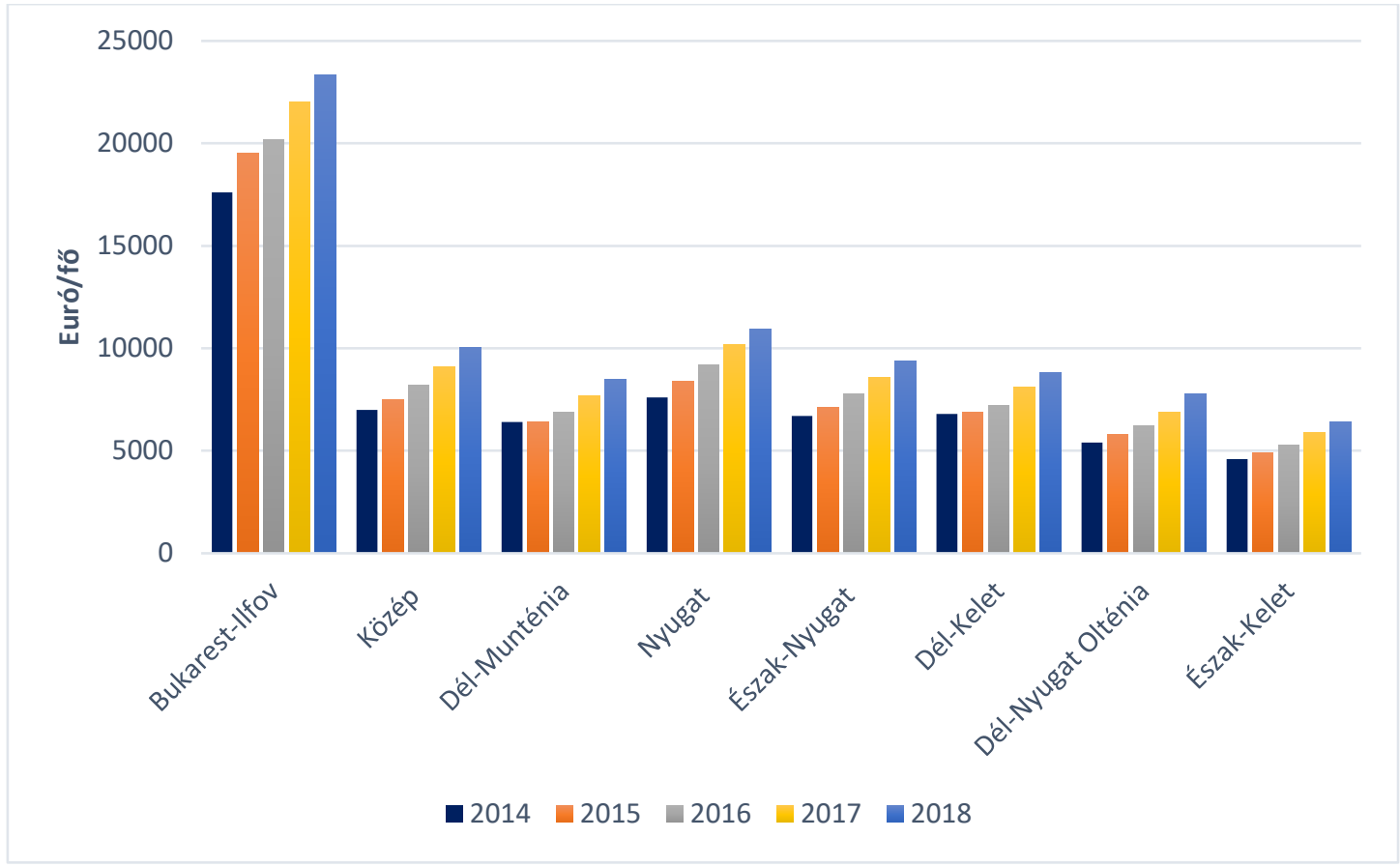

3. ábra GDP/fó Románia régióiban [7] [20]

Az adatok alapján a legkisebb részaránnyal hozzájáruló régiók Dél-Nyugat Olténia, illetve ÉszakKelet Régió. Románia bruttó hazai össztermékének a Dél-Nyugat Olténiai Régió 2017-ben 8,79\%-át 2018-ban 9,14\%-át nyújtotta, valamint az Észak-Keleti régió 2017-ben 7,52\%-át, 2018-ban 7,54\%-át nyújtotta Románia GDP-jének. A 3. ábra adatai alapján látható, hogy a 2014-2018-as időszakban az egy főre jutó GDP aránya minden régió esetében növekedett, de a növekedés üteme nem egyenletes, amelynek egyik következménye, hogy megnövekedett a régiók közötti gazdasági különbség is [19] [9] [18]. A gazdasági különbség növekedését több tényező is befolyásolja, olyan egymással összefüggő gazdasági változók módosulása váltja ki, mint a kereslet, a jövedelem, a beruházások, a termelés, az infrastruktúra, a munkaerő, a tőke. A gazdasági egyenlőtlenség kialakulásához hozzájárul az a tény is, hogy a mobilis tényezők (munkaerő, tőke) a periférikus régiókból a központ felé irányulnak [10].

A Curs de Guvernare által készített 2018-as elemzés, amely az Országos Előrejelzési és Stratégiai Bizottság (CNSP) adatait használta fel, elmondható, hogy a Közép régió tekintetében a nagy regionális központok közül Brassó megye járult hozzá legkisebb arányban az ország gazdasági teljesítményhez (GDP-jéhez) 2017-ben, de ez a hozzájárulási arány a legkisebb a másik hat nagy regionális központ teljesítményéhez viszonyítva [20] [7]. A Közép régióban található Kovászna megye gazdasági teljesítménye a leggyengébb volt 2017-ben, ugyanis 6\%-kal járult hozzá az ország GDP-jéhez. A megyék gazdasági teljesítményét vizsgálva a legkiegyensúlyozottabb térségek a szegényebb régiókban találhatóak és nem a fejlettebb régiókban. Ilyen tekintetben a Közép régió nyilvánult volna a legkiegyensúlyozottabb régiónak a gazdasági teljesítmény tekintetében, ha Kovászna megye gyenge teljesítményét nem vesszük számításba [19] [20] [21].

\section{GDP és az FDI Románia régióiban}

Az FDI², a közvetlen külföldi tőkeberuházások meghatározása Halmos K. (2005, 17.oldal) szerint: " $A$ külföldi müködőtőke beáramlásról akkor beszélhetünk, ha valamely nem hazai gazdasági befektető valamely hazai vállalatban legalább 10\%-os tulajdoni részesedést szerez, vagy részesedését legalább ekkora mértékben növeli. A legfontosabb jellemzője, hogy a befektetô élni kíván a tulajdonosi jogaival, célja egyrészt a jövedelmező befektetés - mint alapmotívum -, másrészt a

\footnotetext{
2 Foreign Direct Investment
} 
külföldi vállalatok feletti részleges vagy teljes kontroll megszerzése révén üzleti céljainak elérése" [19]. A romániai külföldi múködőtőke (FDI) állomány a 2018-as évben országszerte növekedést mutatott. Az Erdélystat 2019 november 12-én készült elemzésében olvasható, hogy az Európai Unió közép-kelet-európai országai közül, abszolút értékben Bulgária áll az utolsó helyen, amely esetében az FDI aránya 42 millió Euró volt 2018-ban, illetve Lengyelország rendelkezik a legnagyobb FDI állománnyal, 196 milliárd Euró volt a 2018-as adatok alapján. Romániában 2007, illetve 2018-as időszakban folyamatosan nőtt az FDI aránya. Erdélyben az FDI állománya 2018-ban közel 19 milliárd Euró volt, ugyanakkor Havasalföldön és Moldvában csupán 13 milliárd Euró volt [21]. A 2. táblázatban látható néhány mutató alakulása a 2018-as évben Románia régiót tekintve.

\section{2. táblázat GDP és FDI [22] [7] [20]}

\begin{tabular}{|c|c|c|c|c|}
\hline $\mathbf{2 0 1 8}$ & $\begin{array}{c}\text { FDI } \\
\text { mill.Euró }\end{array}$ & $\begin{array}{c}\text { FDI aránya } \\
\text { \%-ban }\end{array}$ & $\begin{array}{c}\text { GDP/fó } \\
\text { Euró }\end{array}$ & $\begin{array}{c}\text { Munkanélküliség } \\
\text { \% }\end{array}$ \\
\hline Bukarest-Ilfov & 49250 & 60,7 & 23349 & 1,20 \\
\hline Közép & 7331 & 9,0 & 10023 & 2,90 \\
\hline Dél-Munténia & 5136 & 6,3 & 8486 & 4,00 \\
\hline Nyugat & 6948 & 8,6 & 10940 & 1,80 \\
\hline Észak-Nyugat & 4610 & 5,7 & 9380 & 2,30 \\
\hline Dél-Kelet & 3447 & 4,2 & 8836 & 4,60 \\
\hline Dél-Nyugat Olténia & 2478 & 3,1 & 7791 & 5,90 \\
\hline Észak-Kelet & 1924 & 2,4 & 6426 & 4,80 \\
\hline
\end{tabular}

Területi orientáció szempontjából látható, hogy az FDI koncentrációja a legerőteljesebb BukarestIlfov régióban 60,7\%-os aránnyal, ezt követi a Közép Régió 9,0\%-al és a legkisebb, 2,4\%-os az FDI aránya az Észak-Keleti Régióban. Erdély régiói (Észak-Nyugat régió, Nyugat régió, Közép régió) közül Bánság és Dél-Erdély rendelkezik a legnagyobb FDI-állománnyal, Székelyföld ilyen téren messze elmarad. Erdély (ezen belül Székelyföld), Partium, illetve Bánság történelmi, kulturális térségek, amelyet az erdélyi magyarok használnak. A külföldi befektetők számára egyértelműen a főváros a legvonzóbb, de Románia többi régiójához képest Erdély nagyobb vonzerővel bír. Ami az FDI eredetét illeti, a 2018 decemberi adatok alapján Hollandia volt a legnagyobb FDI befektető 23,9\%-al, ezt követi Németország 12,7\%-al illetve Ausztria 12.2\%-kal. A fenti adatokat nagy mértékben befolyásolja az is, hogy a beruházásokat a vállalatok székhelye szerint jelenítik meg, így abban az esetben, ha jelentős összeget fektetett be egy vállalkozó például a Déli Régióba, Dâmbovița megyébe, ennek ellenére a beruházás a vállalat székhelyén jelenik meg, amely sok esetben Ilfov megye Az FDI területi bontása egy adott vállalat székhelyéhez kapcsolódik, még akkor is, ha nem feltétlenül abba a megyébe, régióba ruháztak be a külföldi befektetők. Azon régiók esetében, ahol alacsony a beruházások aránya, ennek indoka lehet a megfelelő infrastruktúra hiánya, illetve egyik hatása az elszigetelődés [20] [22] [21].

Az FDI és a GDP kapcsolata szoros, vagyis azokban a régiókban, amelyek esetében nagyaobb az FDI aránya, nagyobb a GDP aránya is, míg a munkanélküliségi ráta kisebb. Ez a Bukarest-Ilfov régió esetében be is igazólodott mindkét esetben.

\section{Jövedelmi egyenlőtlenségek}

A KPMG 2018-ban készített egy elemzést, amelynek keretében megvizsgálta az Európai Unió minibálbéreit. Ebben az elemzésben olvasható, hogy Romániában a minimálbér 2018-ban 416 Euró /fő volt, ami a harmadik legkisebb összeg volt az Európai Unió azon országai közül, amelyek gazdasági szabályrendszere alkalmazza a minimálbér intézményét. A legkisebb minimálbér Bulgáriában volt 2018-ban 261 Euró/fő értékkel, míg Luxemburgban a legnagyobb 1999 Euró/fő 
szinttel. Kijelenthető, hogy az Európai Unió területén belül is jelentős a jövedelmi egyenlőtlenség mértéke [23].

A 4. ábra alapján látható, hogy a 2014-2018-as időintervallumban a legmagasabb nettó átlagbérek Bukarest-Ilfov régióban voltak, illetve az is nyilvánvaló, hogy ez így volt az elmúlt évek folyamán is.

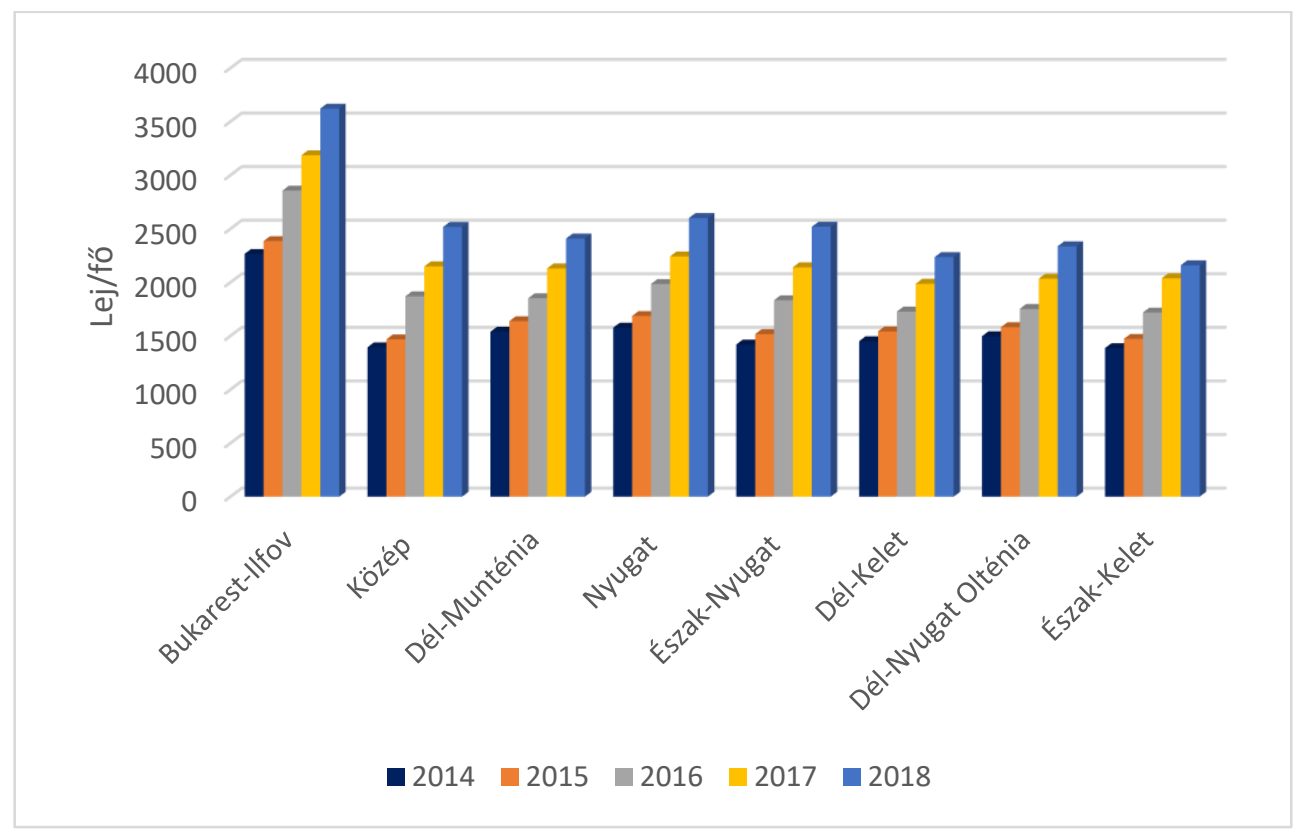

4. ábra Havi nettó átlagbérek Románia régióiban [7] [23] [20]

Az Észak-keleti régió esetében a legalacsonyabb a bérszínvonal, 200o-ben 33\%-kal maradt el a legfejlettebb régió béreitől, majd 2008-ra ez a lemaradás elérte a 38,2\%-ot. 2000-ben 26,7\%-kal haladta meg az országos átlagot a havi nettó átlagbér Bukarest-Ilfov régióban, illetve 2008-ra ez az arány elérte a 41.2\%-ot [9] [18]. Bukarest-Ilfov régióban 2018-ban a havi nettó átlagfizetés 3621 lej/ fó volt, a legmagasabb Románia régiói tekintetében, a legkisebb átlagfizetést pedig az Észak-keleti régióban mérték 2159 lej/fó értékkel. Megyei szinten 2018-ban a Közép régióban, Hargita megyében volt a legkisebb a havi nettó átlagfizetés: 2019 lej/fő. A pólus másik oldalán Bukarestben volt a legnagyobb a havi nettó átlagfizetés 3658 lej/fó értékkel 2018-ban. Megyei szinten is jelentősek a jövedelmi egyenlőtlenségek [19] [9]. Az is látható a 4. ábrán, hogy a 2014-2018-as időszakban folyamatosan emelkedtek a havi nettó átlagbérek minden régióban, de szintén kijelenthető, hogy a növekedés nem járult hozzá a gazdasági egyenlőséghez, inkább a gazdasági egyenlőtlenség mértékének növekedését eredményezte [23] [19].

A koncentrálódás a hazai, illetve a külföldi vállalatok esetében is a képzett munkaerővel és fejlett struktúrával rendelkező térségekben történik, ugyanakkor a jövedelmi egyenlőtlenségek a működőtőke-áramlás felgyorsulásával, koncentrálódásával tovább növekedtek.

\section{5. Összefoglalás}

Románia regionális egyenlőtlenségének vizsgálata esetében kijelenthető, hogy az országra jellemző az erős konvergencia és regionális szinten a gazdasági fejlődés erős területi polarizációja, melyet a fővárosi koncentráció kísér, vagyis a legnagyobb egyenlőtlenséget a Bukarest-Ilfov régió fejlettsége és gazdasági teljesítménye generálja. Bukarest minden gazdasági mutató tekintetében messze kiemelkedik a többi térség közül: az egy főre jutó GDP 23349 Euró/fő volt 2018-ban vagyis az ország hazai össztermékének 27,39\%-át állítja elő, ugyanakkor itt a legalacsonyabb a munkanélküliség, kimagasló a külföldi tókekoncentráció: az FDI arányának több mint 60\%-a koncentrálódik itt. Az előbbiek alapján kijelenthető, hogy az egyenlőtlen regionális fejlődés legfontosabb tényezője a gazdasági fejlődés nagymértékű koncentrációja Bukarestben. Másfelől az eredmények alapján látható, hogy eddig a jelenlegi rendszer múködése sem tudott olyan támogatásokat, lehetőségeket 
nyújtani a periférikus régióknak, amely képes lenne ellensúlyozni a gazdasági, társadalmi egyenlőtlenségek növekedését és segíteni az egyensúly megteremtését. Talán megoldást jelentene erre a problémára, illetve a régiók közötti egyenlőtlenségek enyhítésére a decentralizáció. Miben segítene? Elsősorban a helyi endogén tényezők és szükségletek alaposabb feltérképezésében, hálózati jellegű gazdaságszervezésben, nemzeti szinten való együttmúködésben, nagyobb átláthatóság kialakításában a területi közigazgatások terén és előnyösebb, egyszerübb információszerzésben.

A külföldi múködőtőke-befektetéseknek kiemelkedő jelentősége van a kelet-közép-európai országok gazdaságának fejlődésében. A külföldi múködőtőke kihelyezése során a befektetők mérlegelik a célország földrajzi fekvését, hiszen egyre nagyobb arányban tartják szem előtt a „termelj ahol értékesítesz" elvet, ami Románia esetében is - a vámuniónak köszönhetően - az Európai Unió teljes területét jelenti [26]. A térségek gazdasági fejlődése ugyanakkor nemcsak a külföldi működőtőkétől, hanem a népességmegtartó képességtől is függ [27], amelyek közül a munkalehetőségek meglétét okvetlen ki kell emelni [28]. A munkalehetőségeknek ugyanakkor nemcsak kiszámíthatónak, hanem a lakosság végzettségi szerkezetéhez igazodónak is lennie kell a vidéki térségekben [29]. A megfelelő körülmények megléte esetén a kelet-közép-európai országok is jelentős gazdasági fejlődést érhetnek el [30; 31].

Összegzésképpen a probléma komplexitásából adódóan nem létezik jelenleg olyan megoldás, amely által el lehetne érni a gazdasági és társadalmi egyenlőség csökkentését, csak részleges megoldások vannak, amelyek segíthetnek az egyenlőtlenségek enyhítésében.

Köszönetnyilvánítás: A kutatás az EFOP3.6.3-VEKOP-16-2017-00007 - "Tehetségből fiatal kutató" - A kutatói életpályát támogató tevékenységek a felsőoktatásban. című projekt keretében valósulhatott meg.

Irodalomjegyzék

[1] Dömötör E.-Mátyás L.-Balázsi L.,(2016): A gazdaság térbelisége, városok, régiók, kereskedelem és természeti környezetünk, Közgazdasági Szemle, LXIII . évf., 2016. június (673-696. o.),

[2] European Union (2014): Eurostat regional yearbook 2014, [Online]. Available: https://ec.europa.eu/eurostat/documents/3217494/5785629/KS-HA-14-O01-EN.PDF,

[Megtekintés: 18-Nov-2019]

[3] Európai Bizottság, Regionális Politikai Főigazgatóság (2008): Az Európai Unió regionális politikája 2007-2013 között, [Online]. Available: https://ec.europa.eu/regional_policy/sources/docgener/presenta/working2008/work_hu.pdf, [Megtekintés: 10-Nov-2019]

[4] Lupu L. (2018):Distribuţia spaţială a sărăciei în România,Revista română de sociologie, nr. 5-6, p. $397-418$,

[5] Péli L.(2013): Növekedési pólusok főbb regionális gazdaságtani összefüggéseinek vizsgálata Magyarországon, PhD értekezés, Gödöllő, Szent István Egyetem,

[6] Nemes Nagy J.,(2009): Terek, helyek, régiók, Akadémia kiadó, Budapest.

[7] Instituția Națională de Statistică, (2018): Raport anual 2018, Bukarest, [Online]. Available: http://www.insse.ro/cms/files/raport\%20activitate/raport_anual_2018.pdf, [Megtekintés: 14Nov-2019]

[8] Ladó- Burista R.(2010): Románia küszöbön álló regionális átszervezése, International relations quarterly, Vol I, No.1,

[9] Ceuşescu I.(2018): Short analysis of regional disparities în România, Annals of the „Constantin Brâncuşi” University of Târgu Jiu, Economy Series, 
[10] Benedek J.(2016): Területi polarizáció és periferializáció Romániában, székelyföldi perspektívából, Magyar kisebbség nemzetpolitikai szemle, 21. évf. 79. (1.) sz. /2016

[11] Daniela A. (2012) :Identificarea disparităţilor şi convergenţei economice regionale în Uniunea Europeană şi în România, Academia Română, Instituția Națională de Cercetări Economice,

[12] European Commission(2019) : Country Report Romania 2019 Including an In-Depth Review on the prevention and correction of macroeconomic imbalances, [Online]. Available: https://ec.europa.eu/info/sites/info/files/file_import/2019-european-semester-countryreport-romania_en.pdf, [Megtekintés: 18-Nov-2019]

[13] Agnieszka W. (2019): Regional inequalities in the EU, European Parliamentary Research Service,

[14] Paola A., Lewis D. (2019): The EU regional competitiveness index 2019,Publications Office of the European Union,Luxemburg,

[15] Europa.eu (2019): European Regional Competitiveness Index 2019, [Online]. Available: https://ec.europa.eu/regional_policy/en/information/maps/regional_competitiveness/\#. [Megtekintés: 08-Nov-2019]

[16] Instituția Națională de Statistică (2018), [Online]. Available .http://www.insse.ro/cms/files/publicatii/Romania_in_cifre_breviar_statistic_2018.pdf., [Megtekintés: o8-Nov-2019]

[17] Europa.eu, Eurostat (2017), https://ec.europa.eu/eurostat/statisticsexplained/pdfscache/15100.pdf. Letöltés dátuma:2019.11.14

[18] Borzán A. (2015 ):Nyugat és kelet, avagy Románia területi differenciáltsága,Journal of Central European Green Innovation, 3 (1) pp. 81-96,

[19] Halmos K.(2005): A külföldi múködőtőke és az innovációs képességek kapcsolata és szerepe a felzárkózási folyamatban, Gazdaság- és Társadalomtudományi Kar Közgazdász-gazdálkodási szak,

[20] Comisia Naţională de Strategie şi Prognoză (2019), [Online]. Available

http://www.cnp.ro/user/repository/prognoze/Prognoza_profil_teritorial_primavara_2019.pdf, [Megtekintés: 08-Nov-2019]

[21] Erdelystat.ro,(2019), A külföldi múködőtőke jelentősége Romániában és Erdélyben, [Online]. Available:

http://statisztikak.erdelystat.ro/cikkek/a-kulfoldi-mukodotoke-jelentosege-romaniaban-eserdelyben/39, [Megtekintés: 14-Nov-2019]

[22] Banca Națională a României, bnr.ro,(2018) : Foreign Direct Investment in Romania in 2018, [Online]. Available:

https://www.bnr.ro/PublicationDocuments.aspx?icid=14364. [Megtekintés: o8-Nov-2019]

[23] KPMG-KPMG issues (2018):European minimum wage survey 2018, [Online]. Available: https://home.kpmg/ro/en/home/media/press-releases/2018/05/kpmg-minimum-wagesurvey-2018.html. [Megtekintés: 08-Nov-2019]

[24] Thomas P.,(2015): A tőke a 21. Században,, Budapest: Kossuth Kiadó, 2015, p. 268.oldal.

[25] Europa.eu, „Eurostat,( 2017): Regionális GDP , [Online]. Available:

https://ec.europa.eu/eurostat/statistics-explained/pdfscache/15100.pdf. [Megtekintés: o8Nov-2019]

[26] Németh K. - Kőmíves P. M. (2020): A V4 térség autóiparának innovációja és kihívásai, különös tekintettel a szektor munkaerő iránti igényeire. Magyar Minőség, Vol. 29, No. 1. pp. 10-24. 
[27] Kőmíves P. M. - Szabados Gy. N. - Kulcsár G. - Bácsné Bába É. - Fenyves V. - Dajnoki K. (2018): „Visszatérni vidékre” A sport megtartó ereje. International Journal of Engineering and Management Sciences, Vol. 3, No. 4. pp. 292-307.

[28] Dajnoki K. - Szabados Gy. N. - Kulcsár G. - Kőmíves P. M. - Bácsné Bába É. (2018): „Visszatérni vidékre” - Hallgatói vidékképek kvalitatív megközelítésben. International Journal of Engineering and Management Sciences, Vol. 3, No. 5. pp. 204-216.

[29] Harangi-Rákos M. - Szabó G. (2012): The economic and social role of private farms in Hungarian agriculture. Applied Studies in Agribusiness and Commerce - APSTRACT, Vol. 6, No. 5. pp. 33-41.

[30] Fenyves V. - Pető K. - Szenderák J. - Harangi-Rákos M. (2020): The capital structure of agricultural enterprises in the Visegrad countries. Agricultural Economics - Zemedelska Ekonomika 66, pp. 1-17. (kézirat, megjelenés alatt)

[31] Fenyves V. - Pető K. - Harangi-Rákos M. - Szenderák J. (2019): A Visegrádi országok mezőgazdasági vállalkozásainak gazdasági és pénzügyi helyzete. Gazdálkodás, Vol. 63, No. 6. pp. 459-473. 